Fifth International Conference on Sustainable Construction Materials and

Technologies. http://www.claisse.info/Proceedings.htm

\title{
SMART BIOFAÇADES; AN INNOVATIVE LIVING CONSTRUCTION TECHNOLOGY
}

\author{
F. Fadli ${ }^{*}$, S. Zaina1 ${ }^{1}$ P. Bahrami² \\ ${ }^{1}$ Qatar University, College of Engineering, Department of Architecture \& Urban \\ Planning, Doha, Qatar \\ 2 Optim Design Ltd. USA \\ * Corresponding author: Dr. Fodil Fadli f.fadli@qu.edu.qa
}

\begin{abstract}
Creating comfortable urban built environments is a challenging endeavour in Qatar, due to the rapid development and the prevailing extremely hot climatic conditions. High-rise buildings glazed envelopes and concrete masses result in large amount of solar heat gains, leading to the phenomena of carbon dioxide emissions and the Urban Heat Island (UHI) effect (Fadli et al., 2016). For this purpose, the present study aims at conducting an extensive experimental study to develop a smart innovative bio-green wall system that adapts to the climate of Qatar and the Gulf region. The system will consist of compact lightweight panels -with focus on high-rise buildings- that can be pre-fabricated and customized for mass production. The explorative study aims to design and experiment this innovative living construction material and technology with multiple base materials and planting media. It is meant to be finalized on various functional layers that have to be embedded into a single panel. This innovative passive design device will simplify the idea of green walls and will encourage the application of a new construction material (smart green facades) on high-rise buildings (Fadli, 2017). It will further be incorporated with smart sensing system for watering and maintenance. Enhancing high-rise buildings with smart green facades, besides their striking visual effect, will for sure increase the building energy efficiency. It will also create a wellbeing effect on the psychological and physiological health of individuals and creates natural habitat areas in cities. Furthermore, the experimental results will allow the formulation of a new smart living construction material that would enable the path towards making liveable healthy smart buildings and cities.
\end{abstract}

Keywords: Biofaçades, Smart Living Materials, Innovative Technology, Sustainable Design, Smart Buildings (SBs) and Smart Cities (SCs)

\section{INTRODUCTION}

With the rapid development and the prevailing hot climatic conditions in Qatar, a comfortable urban built environment becomes a difficult task to create. The continuous increase of high-rise buildings envelopes and concrete masses leads to the consumption of intensive amount of solar heat gains, leading to Urban Heat Island effect (Fadli, Zaina, Bahrami, Susorova, and Elwell, 2018). Incorporating as many green elements as possible into the built environment is the only solution for the problem. 
For this purpose, this experimental study, which is part of the Biofaçades research project; developed an innovative green systems for the climate of Qatar and Gulf region. This is aimed to improve the urban environments by reducing $\mathrm{CO} 2$ emissions and the UHI negative impact. The innovative design and development of biofaçades panels aim to improve energy efficiency and create a regional market for this living smart construction material to enhance sustainability in a holistic manner in this extreme hot climatic zone.

\section{EXPERIMENTAL FRAMEWORK}

This section discusses the experimental framework and methodology developed for the study. The framework illustrates the development of the study platform to design and apply innovative processes in the production and manufacturing of a prefabricated green wall system, in the forms of panels, with varying sizes both horizontally and vertically. The aim of the experimental study was to make compact lightweight green panels as an efficient, sustainable system for any built environment and to monitor the thermal performance and carbon dioxide of green panels, in order to measure how they affect the heat transfer through facades, and the local microclimate.

The research project was based in Qatar University (QU). The Biofaçades research team lead all the preparations for the project. The research team started preparatory work for the experiment, which included the collection of project data, site visits, acquisition of materials for the experimental installation, test instruments, and planting materials (containers, soil, and plants) for testing green panels. Based on the literature review and prior research conducted as part of the Biofaçades Project (NPRP 7-1406-2-507), the team determined the best species of plants for the experimental installation (Fadli et al., 2017). The plants were planted in the growing media chosen to be used for the green panel, so that the plants can establish itself when installed into the wall panels.

The Biofaçades research team began the design of the innovative system by conducting market study, to select a suitable material with properties that match the requirement of the project. Followed by this, various functional layers were integrated and chosen based on the inferences and knowledge obtained from Biofaçades and the literature review conducted. The smart planting media and irrigation were also selected by the team to adapt to the climate of Qatar.

\section{MARKET STUDY AND POTENTIAL APPLICATIONS}

There are several green wall systems available in the market. One such example is the Elmich VGM green wall which consists of modular boxes stacked one over the other. The Elmich VGM green wall system is an engineered architectural living wall system comprising VGM® planting modules each with a geotextile media bag, support brackets with covers, anti-lift arms and anchoring pilaster systems. This is paired with a proprietary planting media and an automated drip irrigation-cum-fertilization (fertigation) system to ensure optimum results. Elmich VGM® green wall uses UV-stabilized plastic modules and stainless-steel support brackets and pilasters. The system is certified by independent international test authority to withstand wind uplift from various directions at $110 \mathrm{~km} / \mathrm{h}$ (Elmich, 2012). 


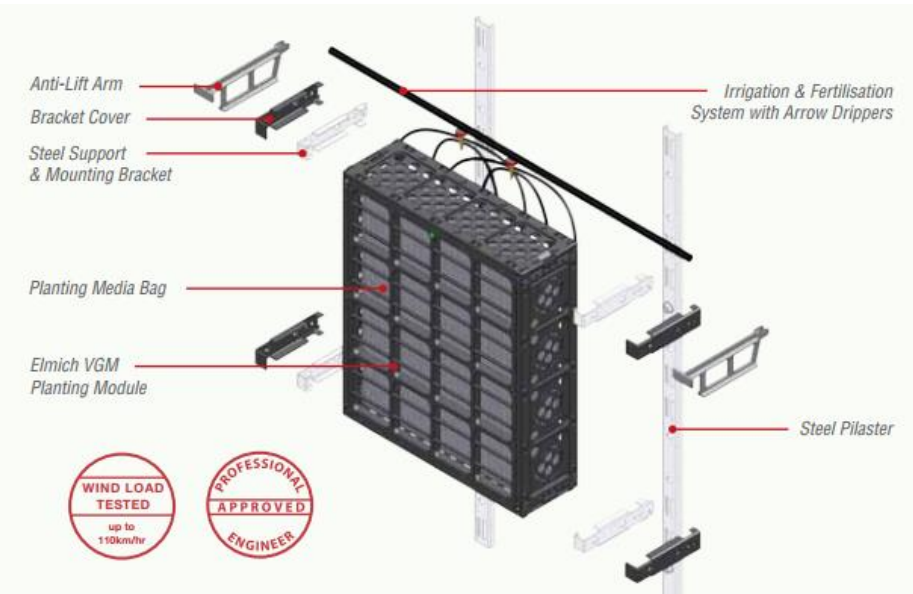

Figure 1. Elmich VGM® Green Wall (Elmich, 2012)

Irrigation and maintenance is a major challenge for a green wall, as irrigation being provided from top to bottom may not reach every point. There are green wall systems in the market that have tackled this issue by creating green panels, namely gsky ProWall with dripline provided for every row of panel and each panel having six emitters in each panel to ensure even water distribution. This approach prevents dry spots within each panel and encourages uniform growth for the plants (gsky, 2012).

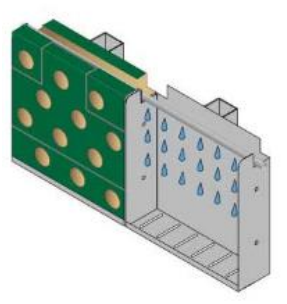

There are 6 emitters in each panel, one every $2 "(5 \mathrm{~cm})$ to
water distribution.
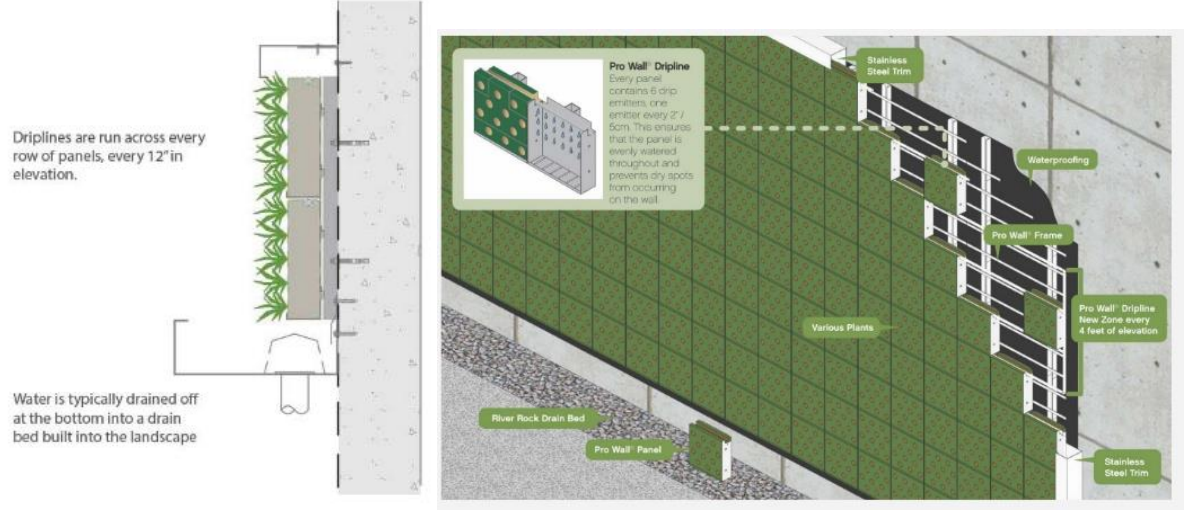

Figure 2. gsky ProWall (gsky, 2012)

Another concern with green wall panels are the planting media, as even distribution of moisture and nutrients is a challenge. There are multiple researches being conducted in the market, exploring this aspect of green wall and new interventions are being made to replace planting soil medium. BiotileTM by Sage Green Life, developed by U.K. based Biotecture, Ltd., has patented hydroponic (soil-less) wall system, which includes modular tiles using layered basalt rock fiber (known as rockwool) that evenly distributes water, oxygen and nutrients and does not decay or break down over time. They provide an ideal rooting and growing environment, resulting in stronger, healthier plants for lasting living walls. Biotile is being explored to install sensors for monitoring water requirements (Sagegreenlife, 2018). 


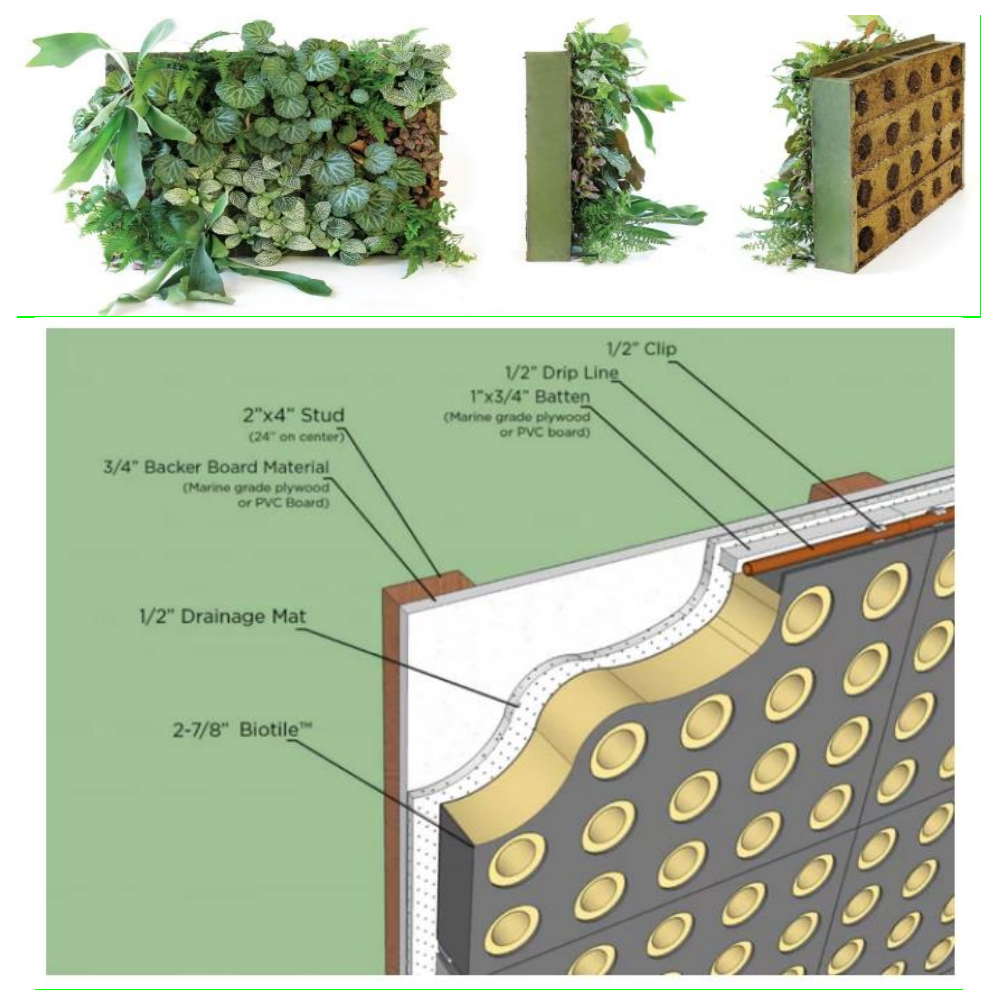

Figure 3. BioTile by Sage Green Life (Sagegreenlife, 2018)

Biotecture sustainable living walls are hydroponic green walls that use Grodan ${ }^{\circledR}$ as growing media for living walls. Gordan is an innovative and sustainable stone wool used for horticulture purposes. Similarly other growing media being used extensively are coconut fiber, coir and HempFlax -hemp straw fibers (Sagegreenlife, 2018).

Most of the green walls in the market are still exploring the aspect of making the green wall a smart system with remote monitoring system. Vicinity green wall system are uniquely designed hexagonal shaped planting modules with soil as the planting media. It is integrated with smart watering system using sensors and remote monitoring unit using hardware, electronics and software. The sensors detect irrigation failures and alerts the customer and operators. The central server and web-based management platform lets customers remotely manage the green wall, with options to change pump and irrigation timing, adjust settings on the irrigation, and set up alerts (Vicinity, 2018). 


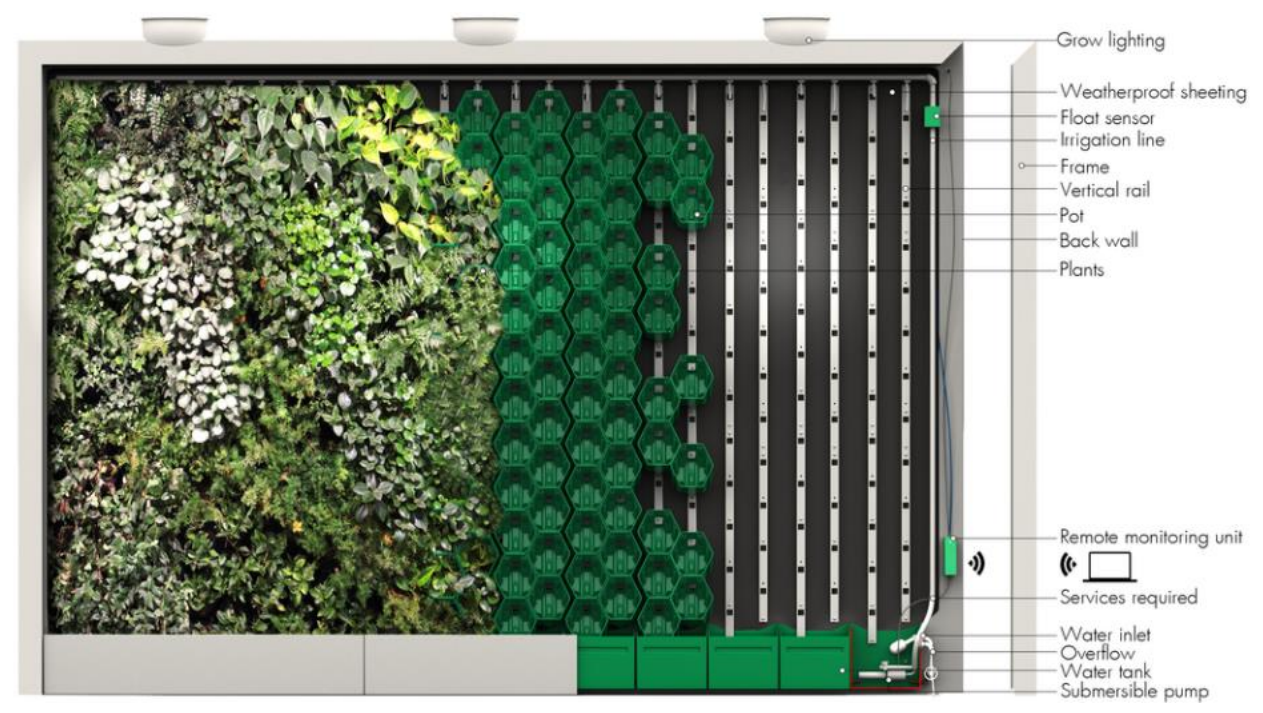

Figure 4. Vicinity Green Wall system (Vicinity, 2018)

The biofaçades green systems at Qatar University alternatively constitutes of a module with custom made planting boxes known as PODs. The PODs are attached to the building exterior using vertical rails. The system consists of plastic barrier, wicking material, geotextile material and aluminium brackets. The water requirement of selected planted species placed in the PODs is met using an in-built manual sub-irrigation system. The subirrigation system is a technique of meeting the plants water demands, where water is brought to the plant root zone from below the soil surface.

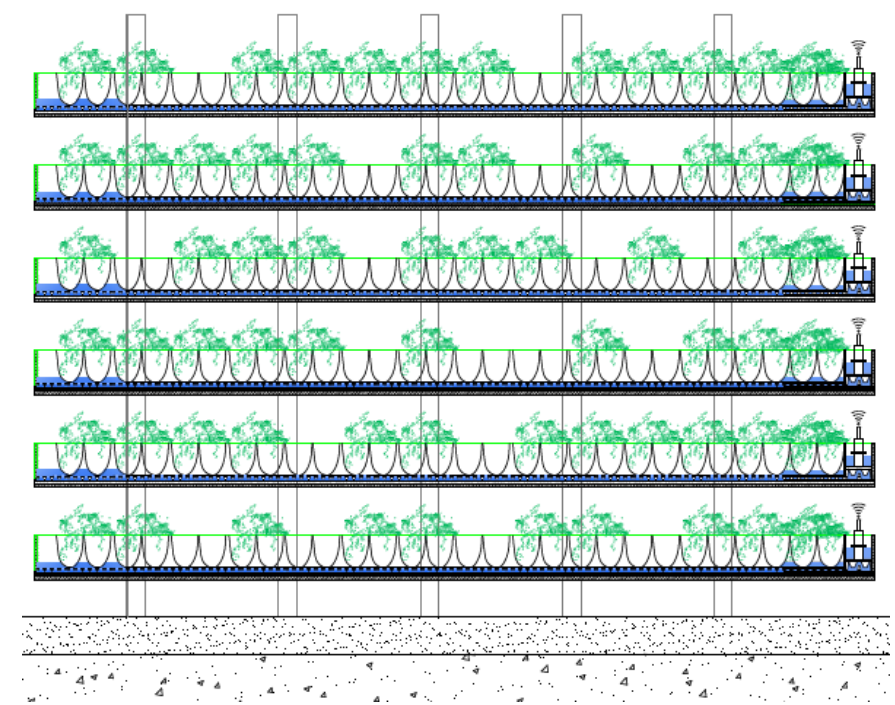

Figure 5. Sub-Irrigation Planter System (SIP) of Biofaçades Module (Authors, 2018)

The PVC PODs consists of water supply shaft, water level indicator, separator and plant liner (Figure 7). The shaft of the water supply serves as mean to add water and liquid fertilizers required for the plants. The water level indicator ensures the complete watering control by indicating the level of water in the PODs (maximum or minimum); which assists on checking the water requirement based on the soil moisture of the plants. The plastic barrier segregates the plant liner and the soil medium of the plants within the PODs. Lastly, the plant liner is made of wicking material of geotextile sheets, which allows the required amount of water in the channels to be absorbed by the roots of the plants. 

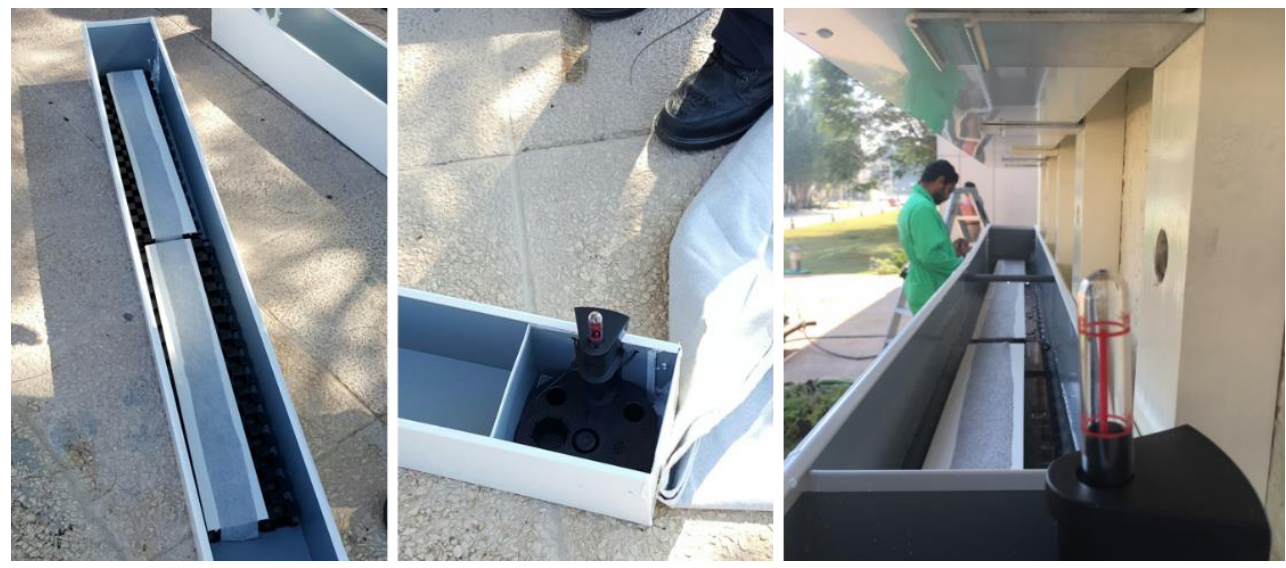

Figure 6: Biofaçades Sub-Irrigation POD System Components Installation (Fadli, F. et al, 2017)

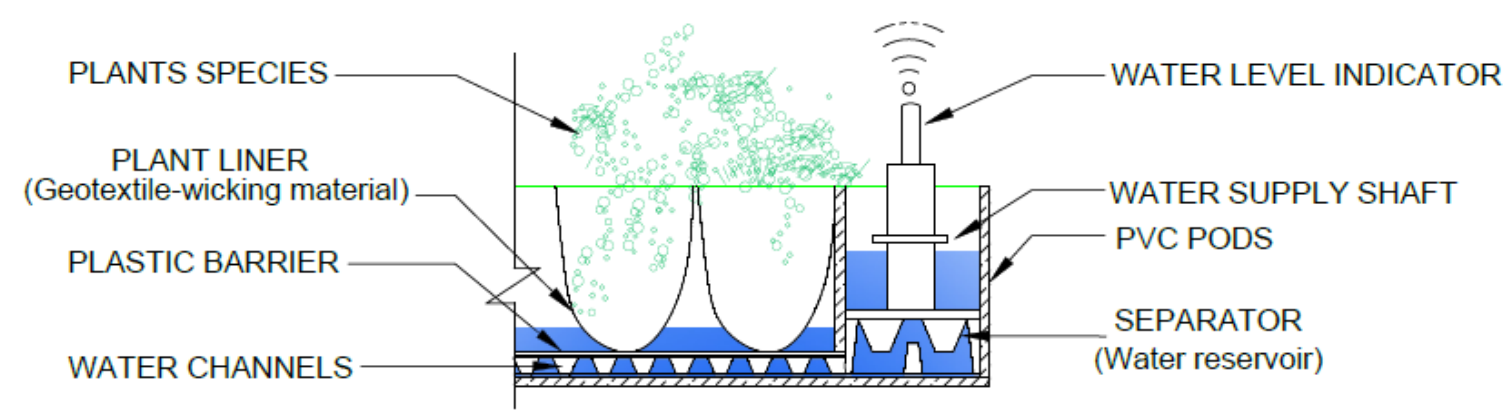

Figure 7: Section Showing the Sub-Irrigation System of Biofaçades (Fadli, F. et al, 2018)

The sub-irrigation system ensures that the plants absorb the required amount of water using capillary action as the water moves from bottom up. The water reservoir developed by the plastic barrier separator and the PVC POD is filled in manually as per the water level indications. The water stored in the reservoir flows through the POD and gets slowly soaked in through the plant liner according to the plants requirements. The water level indicator controls the amount of watering serving as meter controller. This cyclic process is constantly repeated. Circulation of water through the SIP is shown in Figure 8. During the watering process, it had to be insured that all plants have direct contact with the wicking material of the POD to absorb water through its roots. 


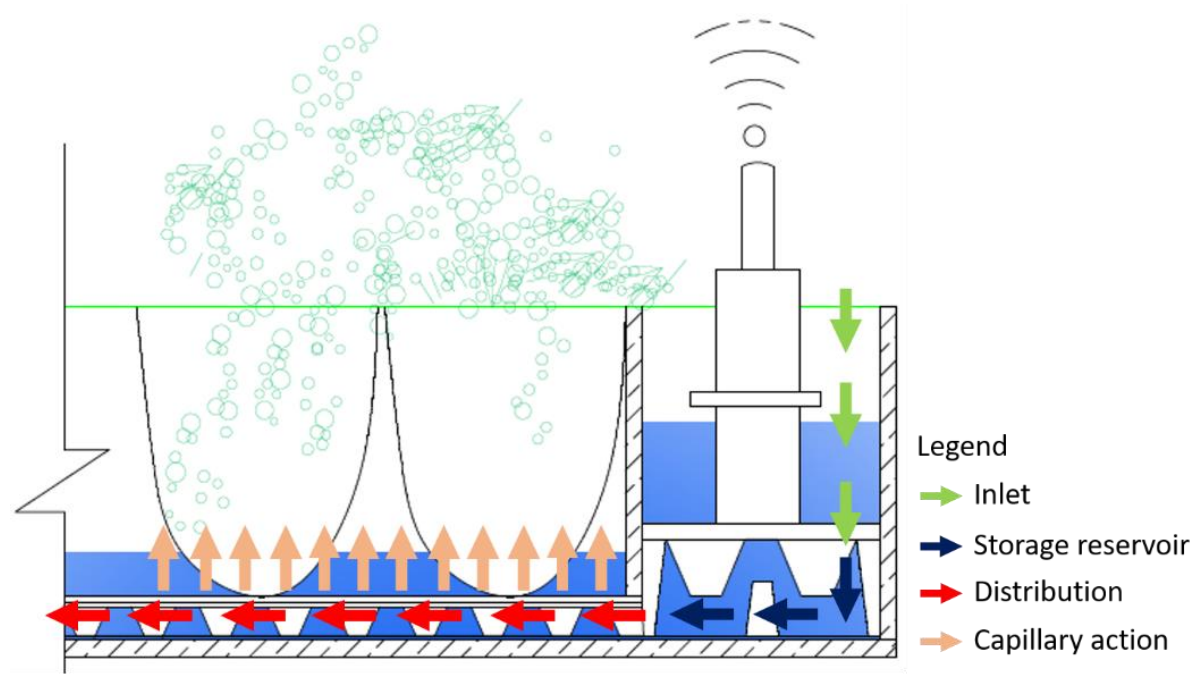

Figure 8: Biofaçades SIP Circulation System (Authors, 2018)

Thus, studying various green wall systems allowed for the improvement of the existing green wall system, and the development of a fabricated new smart green system that is compact, lightweight, and efficient with focus on high rise buildings as discussed in the following section.

\section{RESULTS AND DISCUSSION}

The experimental results allow the formulation of a new smart living construction material that would enable the path towards making liveable healthy smart buildings and cities. The observations made from the experiments and literature is analyzed to refine and modify the innovation to develop a prefabricated green panel which improved the thermal performance of the facades and thereby, improve the urban microclimate.

The amount of solar radiation transmitted to the exterior wall surface behind green walls decreases exponentially with leaf area index (LAI) (Campbell, 1998). The LAI is the total projected area of leaves per unit surface area, which varies with the plant canopy structure, maturity, foliage density, and plant leaf size.

The shading effect of green facades and living walls is the most important in hot climates all year long and in cool climates during hot months when the façade temperature tends to become extremely hot, depending on the wall material, surface properties, and orientation. When covered by a green façade or a living wall, the surface temperature of the exterior wall is typically lower than in the case of a bare facade. During the day, facade exterior surface temperature is reduced by an average of $\pm 3{ }^{\circ} \mathrm{C}-3.5^{\circ} \mathrm{C}$ reaching a maximum of $13.9^{\circ} \mathrm{C}-24.1^{\circ} \mathrm{C}$, as was demonstrated by several previous studies (Chen, 2013; Di, 1999; Evmorfopoulou, 2009; Perez, 2011; Perini, 2011; Price, 2010; Susorova, 2013, Susorova, 2014; Wong, 2010). The highest decrease in wall surface temperature occurred during daytime in sunny weather. For the internal walls, the surface temperatures of both the bare and Bio-Façade covered walls were very close because the indoor spaces used for the experimental setup were all air-conditioned to indoor space temperature of $22^{\circ} \mathrm{C}-24^{\circ} \mathrm{C}$. This shows that adding a vegetated wall to a building envelope in a hot climate has the main benefit in blocking unwanted heat gains into a building right at its exterior boundary. The statistics of the measured surface temperatures for the entire year are shown in Table 1 (NPRP-07-1406-2-507, 2018). 
Table 1. Experimental measurements of facade surface temperature for a one-year period (Fadli et al. 2018, the National Priority Research Program NPRP award [NPRP-07-1406-2507])

\begin{tabular}{|c|c|c|c|c|c|c|}
\hline & \multicolumn{3}{|c|}{ Bare wall surf. temperature $\left({ }^{\circ} \mathrm{C}\right)$} & \multicolumn{3}{|c|}{ BioFacade surf. temperatures $\left({ }^{\circ} \mathrm{C}\right)$} \\
\hline & \multirow[t]{2}{*}{$\begin{array}{l}\text { External } \\
\text { wall }\end{array}$} & \multirow[t]{2}{*}{$\begin{array}{l}\text { Internal } \\
\text { wall }\end{array}$} & \multicolumn{2}{|c|}{$\begin{array}{l}\text { Extern wall } \\
\text { al }\end{array}$} & \multicolumn{2}{|c|}{$\begin{array}{l}\text { Intern wall } \\
\text { al }\end{array}$} \\
\hline & & & Top & Bottom & Top & Bottom \\
\hline \multicolumn{7}{|c|}{$\begin{array}{l}\text { Northw orientation } \\
\text { est }\end{array}$} \\
\hline $\operatorname{Max}$ & $\begin{array}{l}52 . \\
6\end{array}$ & 31.4 & 43.9 & 44.2 & $\begin{array}{l}29 . \\
8\end{array}$ & 29.4 \\
\hline Mean & $\begin{array}{l}32 . \\
0\end{array}$ & 26.4 & 27.6 & 27.5 & $\begin{array}{l}25 . \\
1\end{array}$ & 25.0 \\
\hline Min & $\begin{array}{l}12 . \\
4\end{array}$ & 16.1 & 9.4 & $\begin{array}{l}9 . \\
3\end{array}$ & $\begin{array}{l}17 . \\
0\end{array}$ & 17.0 \\
\hline St. dev. & 7.6 & 4.4 & 6.9 & $\begin{array}{l}6 . \\
8\end{array}$ & 3.6 & $\begin{array}{l}3 . \\
4\end{array}$ \\
\hline $\begin{array}{l}\text { Count } \\
\text { St. error }\end{array}$ & $\begin{array}{l}67526 \\
0.0 \\
3 \\
\end{array}$ & $\begin{array}{l}77876 \\
0.02\end{array}$ & $\begin{array}{c}105115 \\
0.02\end{array}$ & $\begin{array}{l}105115 \\
0 . \\
0\end{array}$ & $\begin{array}{l}105023 \\
0.0 \\
1 \\
\end{array}$ & $\begin{array}{r}105023 \\
0.01\end{array}$ \\
\hline \multicolumn{7}{|c|}{ Southwest orientation } \\
\hline $\operatorname{Max}$ & $\begin{array}{l}58 . \\
8\end{array}$ & 31.4 & 43.3 & 43.2 & $\begin{array}{l}29 . \\
8\end{array}$ & 29.5 \\
\hline Mean & $\begin{array}{l}34 . \\
2\end{array}$ & 26.5 & 28.6 & 28.5 & $\begin{array}{l}25 . \\
2\end{array}$ & 25.1 \\
\hline Min & $\begin{array}{l}10 . \\
3\end{array}$ & 16.2 & 9.8 & $\begin{array}{l}9 . \\
9\end{array}$ & $\begin{array}{l}17 . \\
1\end{array}$ & 17.2 \\
\hline St. dev. & $\begin{array}{l}10 . \\
1\end{array}$ & 4.4 & 7.0 & $\begin{array}{l}6 . \\
8\end{array}$ & 3.6 & $\begin{array}{l}3 . \\
4\end{array}$ \\
\hline $\begin{array}{l}\text { Count } \\
\text { St. error }\end{array}$ & $\begin{array}{l}71580 \\
0.0 \\
4 \\
\end{array}$ & $\begin{array}{l}77876 \\
0.02\end{array}$ & $\begin{array}{l}99370 \\
0.02\end{array}$ & $\begin{array}{c}105109 \\
0.02\end{array}$ & $\begin{array}{l}105023 \\
0.0 \\
1 \\
\end{array}$ & $\begin{array}{r}105022 \\
0.01\end{array}$ \\
\hline \multicolumn{7}{|c|}{ Northeast orientation } \\
\hline $\operatorname{Max}$ & $\begin{array}{l}51 . \\
3\end{array}$ & 27.9 & 41.1 & 41.0 & $\begin{array}{l}29 . \\
0\end{array}$ & 28.4 \\
\hline Mean & $\begin{array}{l}31 . \\
7\end{array}$ & 22.0 & 26.9 & 27.0 & $\begin{array}{l}23 . \\
7\end{array}$ & 23.4 \\
\hline Min & $\begin{array}{l}10 . \\
2\end{array}$ & 15.5 & 10.3 & 10.1 & $\begin{array}{l}15 . \\
2\end{array}$ & 15.5 \\
\hline
\end{tabular}




\begin{tabular}{lllllll} 
St. dev. & 8.4 & 2.5 & 6.5 & 6. & 3.9 & 3. \\
& & & & 4 & & 6 \\
Count & 71298 & 79630 & 105114 & 105113 & 105023 & 105023 \\
St. error & 0.0 & 0.01 & 0.02 & 0.02 & 0.0 & 0.01 \\
& 3 & & & & 1 & \\
\hline Southeast orientation & & & & & \\
\hline Max & 51. & 28.0 & 42.6 & 42.6 & 28. & 28.3 \\
& 0 & & & & 1 & \\
Mean & 32. & 22.8 & 27.6 & 27.6 & 23. & 23.4 \\
& 4 & & & & 4 & \\
Min & 11. & 15.4 & 10.2 & 10.3 & 15. & 15.6 \\
& 1 & & & & 6 & \\
St. dev. & 8.1 & 2.8 & 6.9 & 6. & 3.6 & 3. \\
& & & & 9 & & 6 \\
Count & 70709 & 73094 & 105116 & 105116 & 100203 & 105022 \\
St. error & 0.0 & 0.01 & 0.02 & 0.02 & 0.0 & 0.01 \\
& 3 & & & & 1 & \\
\hline
\end{tabular}

By contrast, during the night, the exterior temperatures of plant-covered facades are 1$2^{\circ} \mathrm{C}$ higher than those of bare facades. It is higher because the vegetative layer prevents night time cooling of the wall. It is prevented by longwave radiation to the sky and/or convection to the outdoor air (Fadli, 2018; Susorova, 2013Hoyano, 1988).

The most significant surface temperature reductions between the bare and the plantcovered exterior walls are recorded during the peak exposure to solar radiation for each facade. In fact, the largest surface temperature reduction is often observed on the east and west facades that are exposed to high-intensity solar radiation in early morning and late evening at low sun angles.

The façade surface temperature is important as it affects the wall temperature gradient, and the difference in temperatures between the facade exterior and interior surfaces. The exterior surface temperature fluctuates significantly during the day depending on the amount of solar radiation and air temperature. Alternatively, the temperature of the interior surface facing an air-conditioned space is relatively stable. By reducing the facade temperature gradient, the plant layer helps decrease the heat conduction through exterior walls. This is a large contributing factor to building cooling energy use in hot climates, depending on; (1) building size, (2) area of the envelope, (3) building type and activities, and (4) severity of the climate. Therefore, green walls has multiple advantages as it helps to reduce building cooling energy consumption, the associated energy cost and negative impact on the environment (Fadli, 2017).

With proper plant selection, a green wall has the ability to significantly absorb greenhouse gases such as carbon dioxide and other pollutants improving the air quality. It has been estimated that for every squared meter of greenery a minimum of $300 \mathrm{~g} \mathrm{CO} 2$ is removed, which can remove up to 6 cubic feet of $\mathrm{CO} 2$ gas per year. Plants are used to improve the quality of air and target pollutants such as carbon monoxide, formaldehyde, and other common

VOC's 


\begin{tabular}{|c|c|c|c|c|c|c|c|c|c|}
\hline & \multicolumn{3}{|c|}{$\begin{array}{l}\text { Carbon Monoxide } \\
\text { (ppm) }\end{array}$} & \multicolumn{3}{|c|}{ Formaldehyde (ppm) } & \multicolumn{3}{|c|}{ TVOC's (ppb) } \\
\hline & 恶 & $\begin{array}{l}\overline{\bar{z}} \\
\bar{E}\end{array}$ & 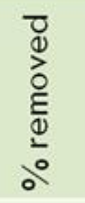 & $\overline{\underline{\underline{E}}}$ & 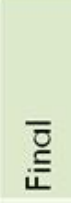 & 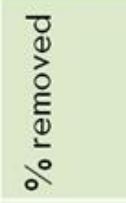 & 铐 & 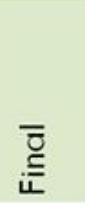 & 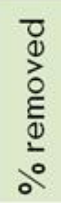 \\
\hline Chlorophytum & 35 & 16 & 55 & 19 & 5 & 73 & 359 & 188 & 47 \\
\hline Dracaena & 34 & 9 & 73 & 18 & 8 & 56 & 378 & 175 & 54 \\
\hline Epipremnum & 28 & 16 & 46 & 18 & 5 & 72 & 340 & 122 & 64 \\
\hline Ficus & 25 & 20 & 20 & 20 & 12 & 40 & 385 & 323 & 16 \\
\hline Hedera & 34 & 18 & 47 & 21 & 10 & 52 & 366 & 159 & 57 \\
\hline
\end{tabular}

Figure 9). Plants such as Dracaena, Chlorophytum, and Epipremnum have the capability to reduce approximately fifty percent of the pollutant's initial concentrations (Mathew \& Salot, 2016).

\begin{tabular}{|c|c|c|c|c|c|c|c|c|c|}
\hline & \multicolumn{3}{|c|}{$\begin{array}{c}\text { Carbon Monoxide } \\
\text { (ppm) }\end{array}$} & \multicolumn{3}{|c|}{ Formaldehyde (ppm) } & \multicolumn{3}{|c|}{ TVOC's (ppb) } \\
\hline & 童 & 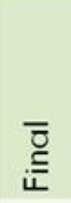 & 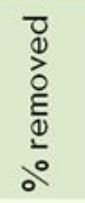 & $\stackrel{\overline{\underline{\underline{E}}}}{\underline{\underline{\underline{E}}}}$ & 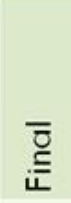 & 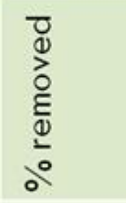 & 吾 & $\sum_{i}^{\bar{E}}$ & 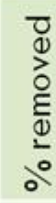 \\
\hline Chlorophytum & 35 & 16 & 55 & 19 & 5 & 73 & 359 & 188 & 47 \\
\hline Dracaena & 34 & 9 & 73 & 18 & 8 & 56 & 378 & 175 & 54 \\
\hline Epipremnum & 28 & 16 & 46 & 18 & 5 & 72 & 340 & 122 & 64 \\
\hline Ficus & 25 & 20 & 20 & 20 & 12 & 40 & 385 & 323 & 16 \\
\hline Hedera & 34 & 18 & 47 & 21 & 10 & 52 & 366 & 159 & 57 \\
\hline
\end{tabular}

Figure 9: Top Biofacade Plants for Air Purification (Mathew \& Salot, 2016)

Moreover, the green wall systems are bulky modular structures and requires regular maintenance from the user end. The systems are limited in terms of remote irrigation and monitoring. Therefore, the research developed a fabricated new green wall system that is compact, lightweight, and efficient with focus on high rise buildings. This new system also bridge the existing market limitation by integrating electronics and computer aided monitoring for irrigation and notification purposes.

The new green wall system has a base/frame with a material suitable for the high-rise buildings in the hot region. The base frame can be clipped using a light frame structure with minimal effort. A sustainable planting media, similar to Coconut fiber mat or Rockwool or Stonewool or HempFlax-grade fiber, was developed and tested to withstand the wind and pressures experienced in high rise buildings. Gravity is another factor that plays key role as it will pull down all the soil in a vertical plane. The planting angle have been identified based on the plants type, planting media is selected and consists of rockwool, soil and water. Keeping these factors in mind, the new green bio-tile will be industry manufactured cladding tile, that can be used like any other cladding finish being used. 
The innovative green panel is incorporated with the necessary support system and is tested for all environmental conditions, needed to be implemented on high rise building facades in Qatar.

The important aspects of the plant cooling effect is the method of irrigation and the attachment of plants onto a vertical surface. Irrigation method and planting media together determine the sustainability of the innovation, and so variations of both these criteria's were developed. A smart irrigation system was integrated using sensors and remote monitoring systems, to develop a more efficient green wall system. Thus, the experimental results aided to simplify the application of green walls into the built environment, including high-rise buildings in hot arid regions.

\section{CONCLUDING REMARKS}

The new innovative smart biofacades system provides existing and planned buildings with the benefits of an enhanced green wall system. These benefits include visual benefits, lower energy requirement, a more suitable micro-climate, acoustic insulation, biofiltering, healthy environments and economic savings. Biofaçade systems also allow the reduction of the facade exterior and interior surface temperatures, air relative humidity, and heat flux through the walls.

Those innovative construction materials and systems will operate with low maintenance. They also adopt a user-friendly monitoring for the buildings occupants, as the system is an interactive-smart one. It uses sensors that notify water requirements and also alert the user if any of the panels are not performing well, by monitoring the planting media conditions and meeting the harsh climatic conditions of Qatar and the GCC region.

In conclusion, the experimental results will allow the formulation of a new smart living construction material that would pave the path towards making smart healthy buildings that perform sustainability within resilient agile smart cities.

\section{ACKNOWLEDGMENT}

"This research/publication was made possible by a National Priority Research Program NPRP award [NPRP-07-1406-2-507] from the Qatar National Research Fund (a member of The Qatar Foundation). The statements made herein are solely the responsibility of the author(s)."

\section{REFERENCES}

Campbell, G. S. (1998). An Introduction to Environmental Biophysics. New York: Springer.

Chen, Q. B., Li, B., Liu, X. (2013). "An experimental evaluation of the living wall system in hot and humid climate." Energy and Buildings 61: 298-307.

Di, H. F., Wang, D. H. (1999). "Cooling Effect of Ivy on A Wall." Experimental Heat Transfer 12: 235245.

Elmich. (2012). Elmich VGM® Green Wall-Modular Living Wall System. Australia: Ecospecifier Golbal. 
Evmorfopoulou, E. A., Kontoleon, K. J. (2009). "Experimental approach to the contribution of plant covered walls to the thermal behaviour of building envelopes." Building and Environment 44: 10241038.

Fadli, F. (2018). Next Generation Building [NGB] Design Approach: Green Architecture Techniques and Impact on Urban Liveability. Qatar Green Building Conference "The Challenge". Qatar: QGBC.

Fadli, F., Zaina, S., Bahrami, P., Susorova, I., \& Elwell, K. (2018). BioFacades: Towards Healthy Living and Improved Well-bing of Users. Green Engineering Conference for Qatar Society of Engineers. Qatar: QSE.

Fadli, F. (2017). Sustainability in Building Design and Construction: Passive Design for Buildings in GCC Practical Approach. Sustainability Summit. Qatar: GORD.

Fadli, F., Zaina, S., Kutty, N., Bahrami, P., Susorova, I., \& Elwell, a. K. (2017). BioFacades: Next Generation Building Envelope. Qatar Green Building Conference "The Challenge". Qatar: QGBC.

Fadli, F., Bahrami, P., Susorova, I., Tabibzadeh, M., Zaina, S., \& El-Ekhteyar, E.-S. (2016). Bio-Facades; An Innovative Design Solution Towards Sustainable Architecture in Hot Arid Zones . In ARC'16 (Ed.), Qatar Foundation Annual Research Conference. Qatar: Qatar Foundation.

Gsky. (2012). https://gsky.com/pro/design/\#proplantdesignprocess.

Hoyano, A. (1988). "Climatological uses of plants for solar control and the effects on the thermal environment of a building." Energy and Buildings 11: 181-199.

Mathew, J., \& Salot, A. (2016). Feasibility Study of Green Walls Project Report. University of Illinois.

Pérez, G., Rincón, L., Vila, A., González, J. M., Cabeza, L. (2011). "Green vertical systems for buildings as passive systems for energy savings." Applied Energy 88: 4354-4859.

Perini, K., Ottelé, M., Fraaij, A.L.A., Haas, E. M., Raiteri, R. (2011). "Vertical gardening systems and the effect on air flow and temperature on building envelope." Building and Environment 46: 2287-2294.

Price, J. (2010). Green Facade Energetics. MS Thesis, University of Maryland.

Sagegreenlife. (2018). https://sagegreenlife.com/living-walls-2/.

Susorova, I., Angulo, M., Bahrami, P., Stephens, B. (2013). "A model of vegetated exterior facades for evaluation of wall thermal performance." Building and Environment 67: 1-13.

Susorova, I., Azimi, P., Stephens, B. (2014). "The effects of climbing vegetation on the local microclimate, thermal performance, and air infiltration of four building facade orientations." Building and Environment 76: 113-124.

Vicinity.

modularverticalgarden. http://www.modularverticalgarden.com/\#thesystem.

Wong, N. H., Yong Kwang Tan, A., Chen, Y., Sekar, K., Tan, P. Y., Chan, D., Chiang, K., Wong, N. C. (2010). "Thermal evaluation of vertical greenery systems for building walls." Building and Environment 45: 663-672. 